\title{
The Effect of Evaporation on Strength and the Stability of Thickened Tailings Beach Slopes
}

\author{
K.D. Seddon Australian Tailings Consultants, Australia \\ M.J. Dillon Australian Tailings Consultants, Australia
}

\begin{abstract}
At the time a layer of tailings slurry comes to rest on the surface of a tailings beach and settles, it has very low shear strength. Before additional layers of tailings are placed over this layer, the strength must increase, or the driving forces of the accumulated tailings will exceed the shear strength, and mass instability will result.
\end{abstract}

The undrained shear strength of tailings in a beach is a function of the moisture content and density of the tailings. Test methods to establish this relationship are discussed and compared. The effects of surface area and evaporative drying can be combined to analyse the final moisture content, density and shear strength achieved on a beach. The theoretical results are compared to the results of field trials.

The influence of climate and tailings type can be important. Under critical combinations of climate, tailings and placement rate, very low strength layers may remain in the tailings at depth. In the first instance, a static type failure may result (i.e. a failure without any triggering mechanism such as an earthquake). A possible example of this type of failure is proposed.

\section{Introduction}

It is generally accepted that one of the advantages of thickened tailings disposal, compared to conventional methods, is that a higher storage density is achieved. This effect is due in part to the slightly higher initial settled density that may be achieved using thickened tailings, but the principal contribution is due to the larger exposed surface area, and the resulting rate of rise, that are a consequence of the geometric characteristics of a thickened tailings scheme.

This paper examines the phenomenon of evaporative drying, and the associated issue of strength. The considerations are most applicable for clay type tailings where consolidation rates are slow (e.g. tailings from coal, diamonds, mineral sands etc.), and the undrained strength ratio is low.

For tailings drying on a beach, the main range of interest is between the initial settled condition to a point close to the shrinkage limit. Over this range, the tailings remain saturated, and the equations for shear strength are relatively simple. At moisture content values less than the shrinkage limit (or the air entry value), the material becomes progressively unsaturated, and more complex equations may need to be used. However, experience has shown that soils that have been dried to a moisture content lower than the shrinkage limit have adequate strength for most applications, and a more detailed analysis is not usually required.

\section{Moisture content versus strength}

The fact that the undrained shear strength of a cohesive soil is dependant on moisture content is well documented (Lambe and Whitman, 1979). There are two basic and complementary ways of obtaining this relationship for tailings. The first is through laboratory tests for compression and triaxial strength. These tests are usually carried out on a saturated sample. The second involves laboratory vane shear tests carried out directly in a sample as it is subjected to drying. 
The first approach can be demonstrated by reference to the results of a Rowe cell compression test on a sample of copper tailings, Figure 1. This shows void ratio (e) plotted against vertical effective stress $\left(\sigma_{\mathrm{vo}}{ }^{\prime}\right)$, on a $\log$ scale. The results of tests for initial settled density derived from tray settling tests are also shown. These extend the Rowe cell results to higher void ratios (lower vertical pressures).

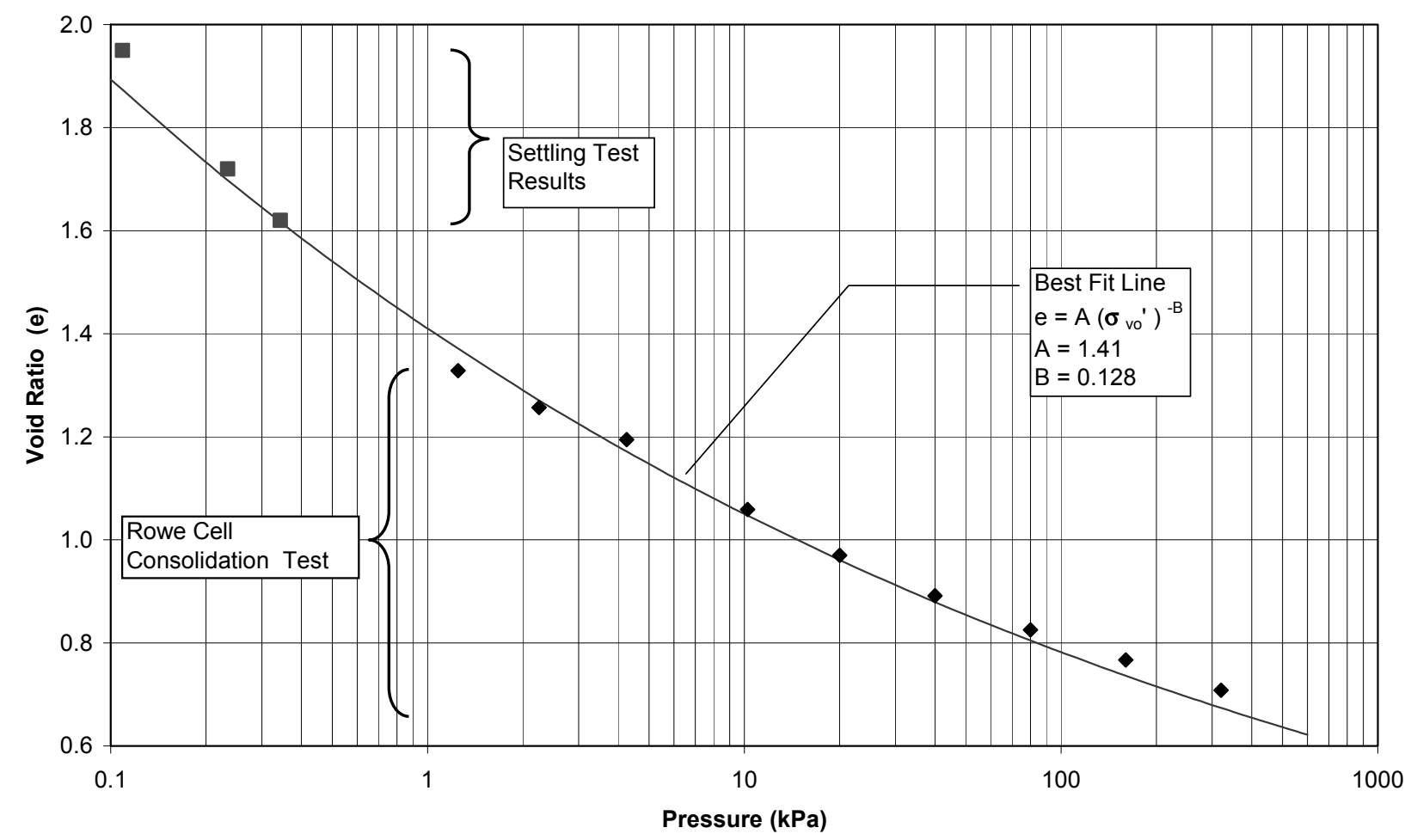

Figure 1 Rowe cell compression test on copper tailings (void ratio versus pressure)

For the range of values required to characterise a tailings sample, a curve of the following form has been found to be appropriate:

$$
\mathrm{e}=\mathrm{A}\left(\sigma_{\mathrm{vo}}{ }^{\prime}\right)^{-\mathrm{B}}
$$

where A and B are experimentally derived parameters. A best fit curve using this equation is shown on Figure 1. Inverting this, and noting the relationship between moisture content $(\mathrm{m})$ and void ratio (refer Appendix) gives:

$$
\sigma_{\mathrm{vo}}{ }^{\prime}=[\mathrm{mG} / \mathrm{A}]^{-1 / \mathrm{B}}
$$

There is also a well accepted empirical relationship between undrained shear strength $\left(\mathrm{S}_{\mathrm{u}}\right)$ and effective stress (Seddon, 2007):

$$
\mathrm{S}_{\mathrm{u}}=\mathrm{k} \sigma_{\mathrm{vo}}{ }^{\prime}
$$

where $\mathrm{k}$ is an empirical constant (the undrained strength ratio), derived from a series of triaxial shear tests. Combining Equations (2) and (3) we obtain the relationship between shear strength and moisture content:

$$
\mathrm{S}_{\mathrm{u}}=\mathrm{k}[\mathrm{mG} / \mathrm{A}]^{-1 / \mathrm{B}}
$$

In these tests the vertical effective stress $\sigma_{\mathrm{vo}}$ ' is defined by the classic equation (Terzaghi and Peck, 1967):

$$
\sigma_{\mathrm{vo}}{ }^{\prime}=\sigma_{\mathrm{vo}}-\mathrm{u}
$$

where:

$\sigma_{\mathrm{vo}}$ is total vertical stress.

$\mathrm{U} \quad$ is pore water pressure. 
Pore water pressure may be either positive (in which case it acts to reduce effective stress), or negative (thereby acting to increase effective stress). A concept fundamental to this paper is that the process of drying a soil induces suction (i.e. negative pore pressure), and thereby increases the effective stress, even though the soil may be at the surface or at shallow depth, and the total stress is low. This increase in effective stress accounts for both the volume (density) change, and the strength change observed as a tailings sample is dried.

The results of a typical shrinkage limit test (on the same copper tailings as shown in Figure 1) are shown in Figure 2. This indicates that a sample commencing from an initial settled density around $0.75 \mathrm{t} / \mathrm{m}^{3}$ $(\mathrm{m}=98 \%)$ dries back to a final (shrinkage limit density) around $1.60 \mathrm{t} / \mathrm{m}^{3}$. The theoretical curve for $100 \%$ saturation is also shown, and indicates that the tailings remain saturated until very close to the shrinkage limit density.

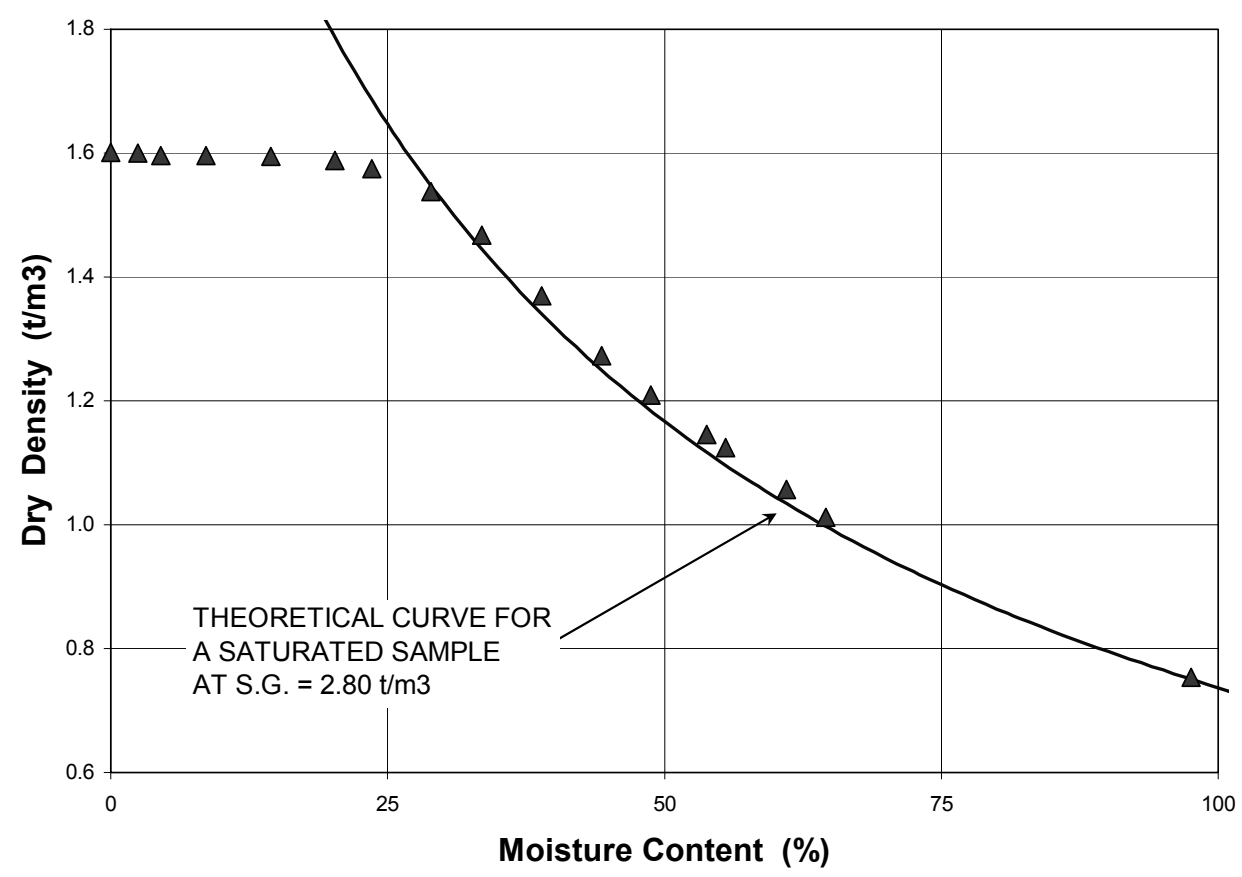

Figure 2 Shrinkage limit density test result

The alternative approach is direct measurement of undrained shear strength using vane shear tests. In this example tests were carried out on the same copper tailings sample for which results are shown in Figures 1 and 2. Vane tests (for both peak and residual undrained strength) were carried out in the same sample at intervals during a drying test. The vane test results are plotted as points in Figure 3 (in which shear strength is in units of $\mathrm{Pa}$ ). It would be possible to simply fit an empirical curve to these data points. However, it is the position of this paper that a much more fundamental understanding of the strength behaviour is obtained if the vane tests are compared to the theoretical Equation (4). The agreement between the two methods is demonstrated in Figure 3, in which the moisture-strength relationships obtained using Equation (4) are plotted as continuous curves. 


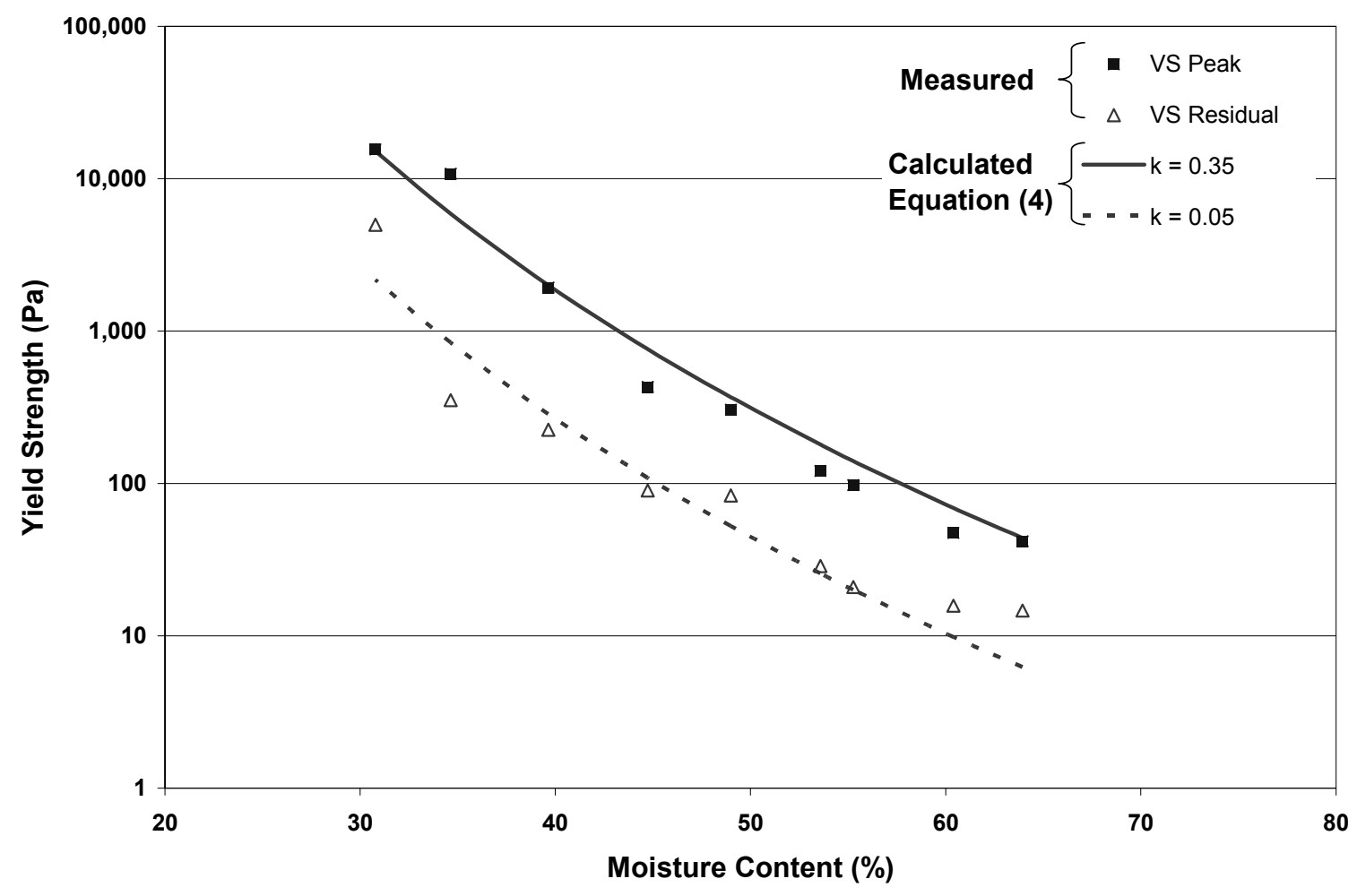

\section{Figure 3 Comparison of vane shear and calculated strength}

\section{Effect of evaporation on moisture content}

In a sub-aerial deposition scheme, (and in particular in the case of thickened/paste tailings), a layer of deposited tailings will typically settle to a density represented by the laboratory test for initial undrained settled density (IUSD). There are exceptions to this. Firstly, in the case of paste tailings it is possible that the underflow density achieved in the thickener may be marginally higher than the IUSD. Secondly, in the case of pipe head flocculation, field trials indicate that the depositional density is better represented by the initial drained settled density (IDSD), which is commonly higher than the IUSD.

The equations presented below use settled dry density $\gamma_{\text {sd }}\left(\operatorname{dry} t / \mathrm{m}^{3}\right)$, and the appropriate value should be used. At the settled density, the initial moisture content $\left(\mathrm{m}_{\mathrm{sd}}\right)$ is calculated as follows:

$$
\mathrm{m}_{\mathrm{sd}}=\left(1 / \gamma_{\mathrm{sd}}-1 / \mathrm{G}\right)
$$

If it is assumed that the only changes in moisture are due to evaporation, the change in mass of water per unit surface area of tailings $\left(\Delta \mathrm{E}\right.$, units of $\left.\mathrm{kg} / \mathrm{m}^{2}\right)$ due to evaporation over any given time period is:

$$
\Delta \mathrm{E}=\mathrm{E}_{\mathrm{pan}} \mathrm{Ec},
$$

where:

$\mathrm{E}_{\mathrm{pan}}$ is total pan evaporation for the period, $\mathrm{mm}$.

Ec is a salinity correction factor (Newson and Fahey, 1998).

There are cases where this assumption is not valid, for example where there is significant upwards seepage due to consolidation. The following equations would then need to be modified to allow for the additional mass flux. A further evaporation correction may also be required if the tailings surface is in a confined location (e.g. in a deep pit), and the $\mathrm{E}_{\mathrm{pan}}$ data are not representative. 
For the case where evaporation is the only cause of moisture change, and a tailings layer of thickness $\mathrm{H}(\mathrm{m})$, the change in moisture content $(\Delta \mathrm{m})$ is:

$$
\Delta \mathrm{m}=\Delta \mathrm{E} /\left(1000 \mathrm{H} \gamma_{\mathrm{sd}}\right)
$$

Therefore the final moisture at the end of the drying period $\left(\mathrm{m}_{\mathrm{f}}\right)$ is:

$$
m_{f}=m_{s d}-\Delta m
$$

The final dry density $\left(\gamma_{\mathrm{df}}\right)$ is calculated by:

$$
\gamma_{\mathrm{df}}=\mathrm{G} /\left(1+\mathrm{m}_{\mathrm{f}} \mathrm{G}\right)
$$

but with the limitation that the final density achieved by evaporative drying cannot exceed the shrinkage limit density, as demonstrated by shrinkage limit tests (Figure 2).

\section{$4 \quad$ Influence of rate of rise}

The annual increase in the depth of tailings, or rate of rise, combined with evaporation directly influences both density and shear strength. The effect can be calculated either for the full year directly, or by summing the results obtained from calculations based on shorter time periods (e.g. monthly).

\section{Example 1:}

Figure 4 shows the effect of rate of rise on density. The individual data points are the calculated incremental dry density for a number of different coal tailings storages in the Hunter Valley, Australia, obtained from annual production figures and surveyed volumes. They represent a direct measurement of density and rate of rise. These storages would not be considered to be thickened tailings schemes, however they are all effectively sub-aerial, and the same considerations apply. The continuous line is based on density calculated in accordance with Equation (10), using a typical IUSD and shrinkage limit density for tailings of this type, and an annual evaporation of around $1500 \mathrm{~mm}$, with no salinity correction. The density is the annual mean, calculated on a monthly basis.

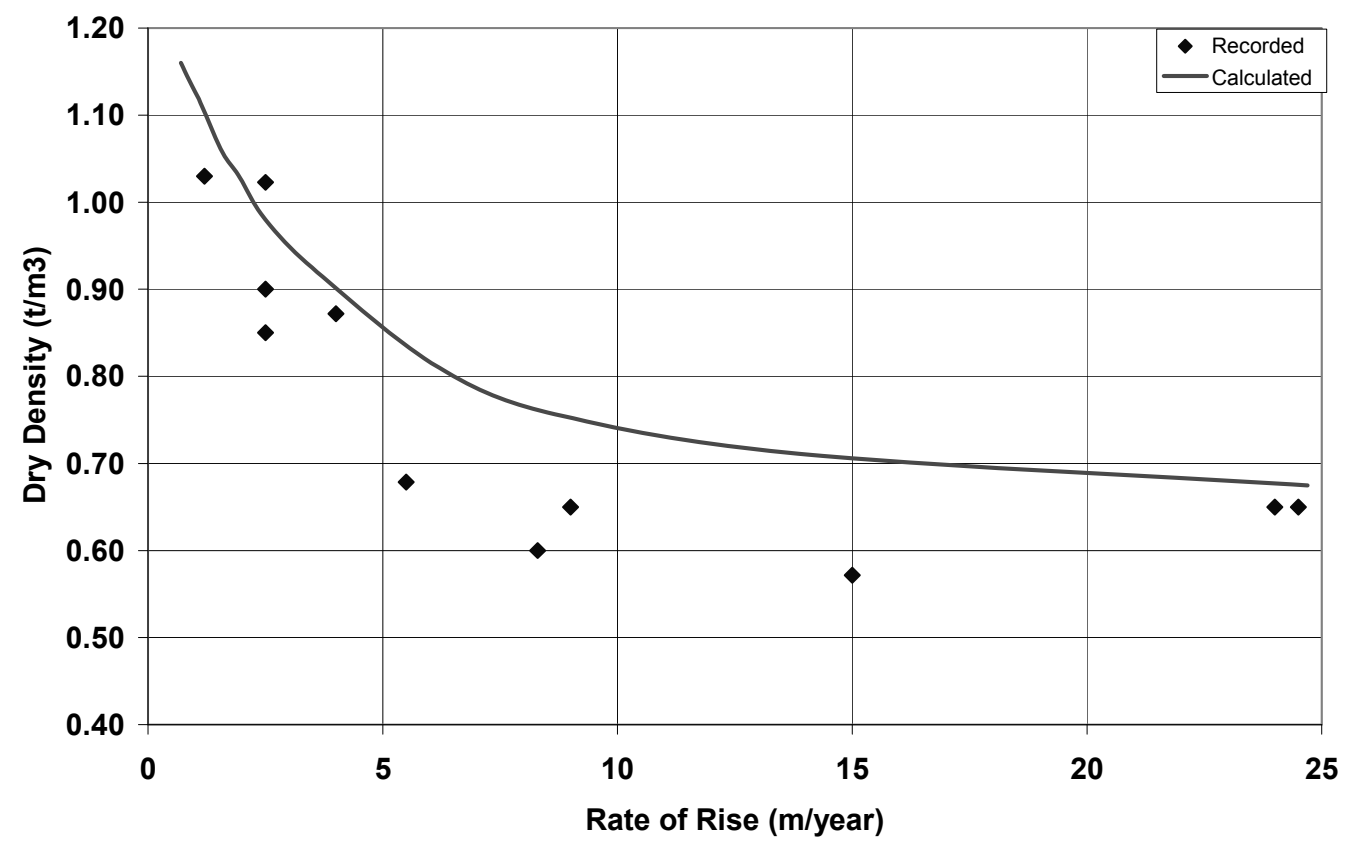

Figure 4 Effect of rate of rise on density 
There is general agreement between the calculated trend and the measured results, although the calculated curve appears to slightly overestimate density at higher rates of rise. This is most likely due to the fact that the curve is based on the properties of just one tailings sample, while the actual data points represent a range of different storages and tailings properties.

\section{Example 2:}

Selected results from a series of field trials (Verburg et al., 2006) carried out at a copper mine in the summer and autumn months are shown in Figure 5. Moisture content and vane shear strength, as well as rainfall and evaporation, were monitored as a series of layers were dried to close to the shrinkage limit density.

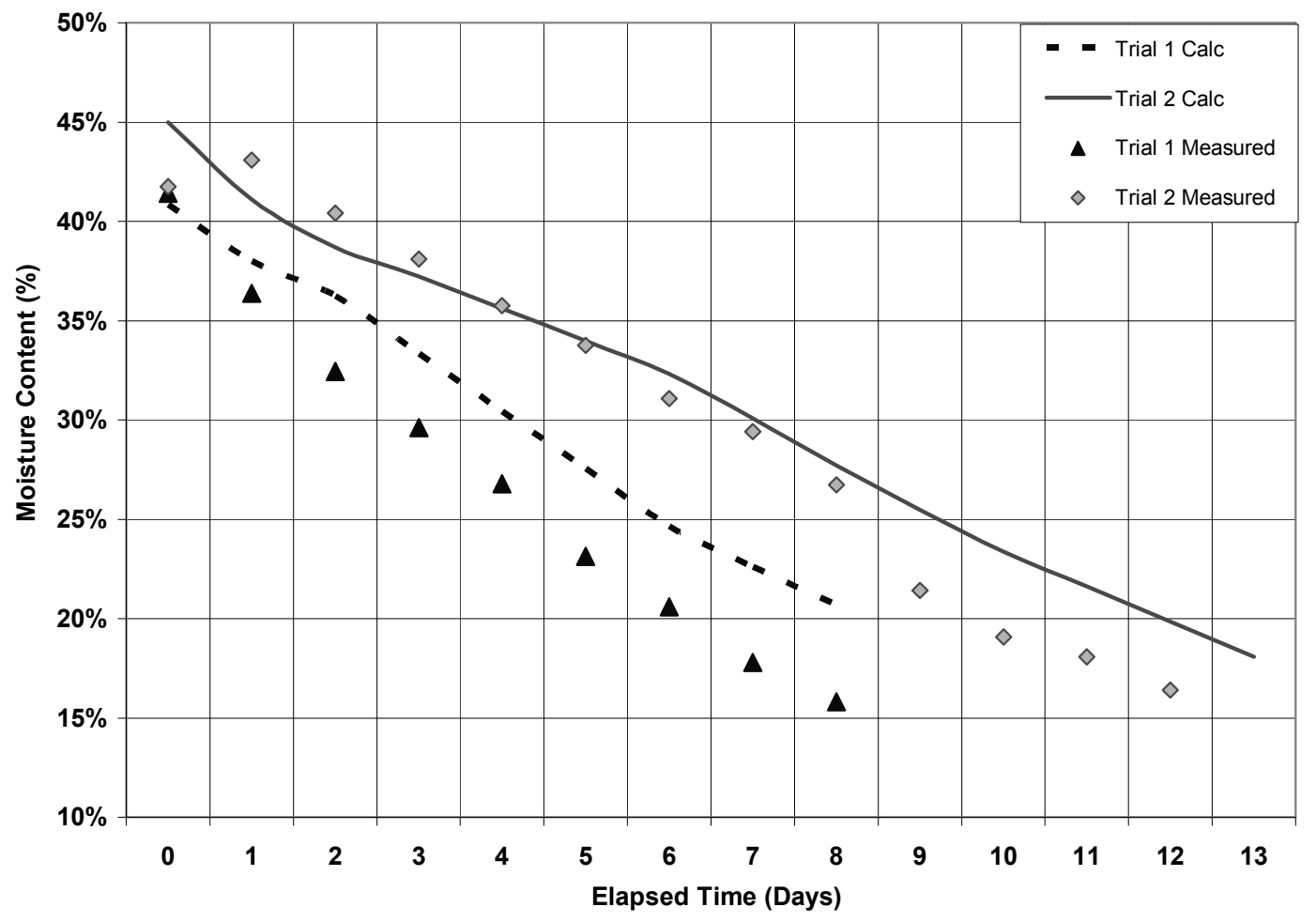

Figure 5 Predicted and measured field moisture content

The data shown are for two layers, each initially $200 \mathrm{~mm}$ thick. The first layer was placed in mid-summer, when the average evaporation rate was around $10.3 \mathrm{~mm} /$ day. The second layer was placed later, when the evaporation rate had reduced to around $7.9 \mathrm{~mm} /$ day. The results may be compared with predictions obtained from Equation (9). It is apparent that good agreement is obtained in the second case. There is some discrepancy in the first case, possibly due to drainage of the layer in addition to evaporative drying.

Measured vane shear strengths at the end of these drying periods were typically greater than $10 \mathrm{kPa}$, which is consistent with the final moisture content values.

\section{$5 \quad$ Seasonal effects on strength and stability}

In most cases, seasonal variations in evaporation rate are significant. They are also site specific, so that these calculations have to be worked through in detail for any individual site. The use of annual average values may be sufficient in cases where only a preliminary estimate of density is required, but shorter time intervals are required for shear strength evaluation.

The following example is based on a study for a thickened discharge scheme for coal tailings. These are high plasticity clay materials. A low soil particle density results in relatively low placement densities, but in other respects the material has similar properties to diamond and mineral sand slimes, and other tailings derived from oxide ore. 
The values used for this analysis are:

$\begin{array}{ll}\text { Soil particle density (G) } & =1.98 \mathrm{t} / \mathrm{m}^{3} \\ \text { Initial settled density (ISD) } & =0.63 \mathrm{t} / \mathrm{m}^{3} \\ \text { Shrinkage limit density (SLD) } & =1.17 \mathrm{t} / \mathrm{m}^{3} \\ \text { Compression parameters } & \mathrm{A}=1.86, \mathrm{~B}=0.21 \\ \text { Shear strength ratio (k) } & =0.20\end{array}$

The annual evaporation is $1750 \mathrm{~mm}$, ranging from $250 \mathrm{~mm} / \mathrm{month}$ in summer, to $50 \mathrm{~mm} / \mathrm{month}$ in winter.

The calculation for undrained shear strength was carried out on a monthly basis, using Equations (7) and (9), for annual rates of rise of one, two and three metres. The results are shown on Figure 6.

It should be noted that this approach effectively assumes that the permeability of the deposited tailings is low and that there is no subsequent re-distribution of moisture content between adjacent layers, and that consolidation effects do not eventually result in compression and a further gain is strength. Both these possibilities were checked for the example shown in Figure 6 using more detailed analyses (GeoStudio program Vadoze/W and consolidation analysis respectively), and did not influence the result.

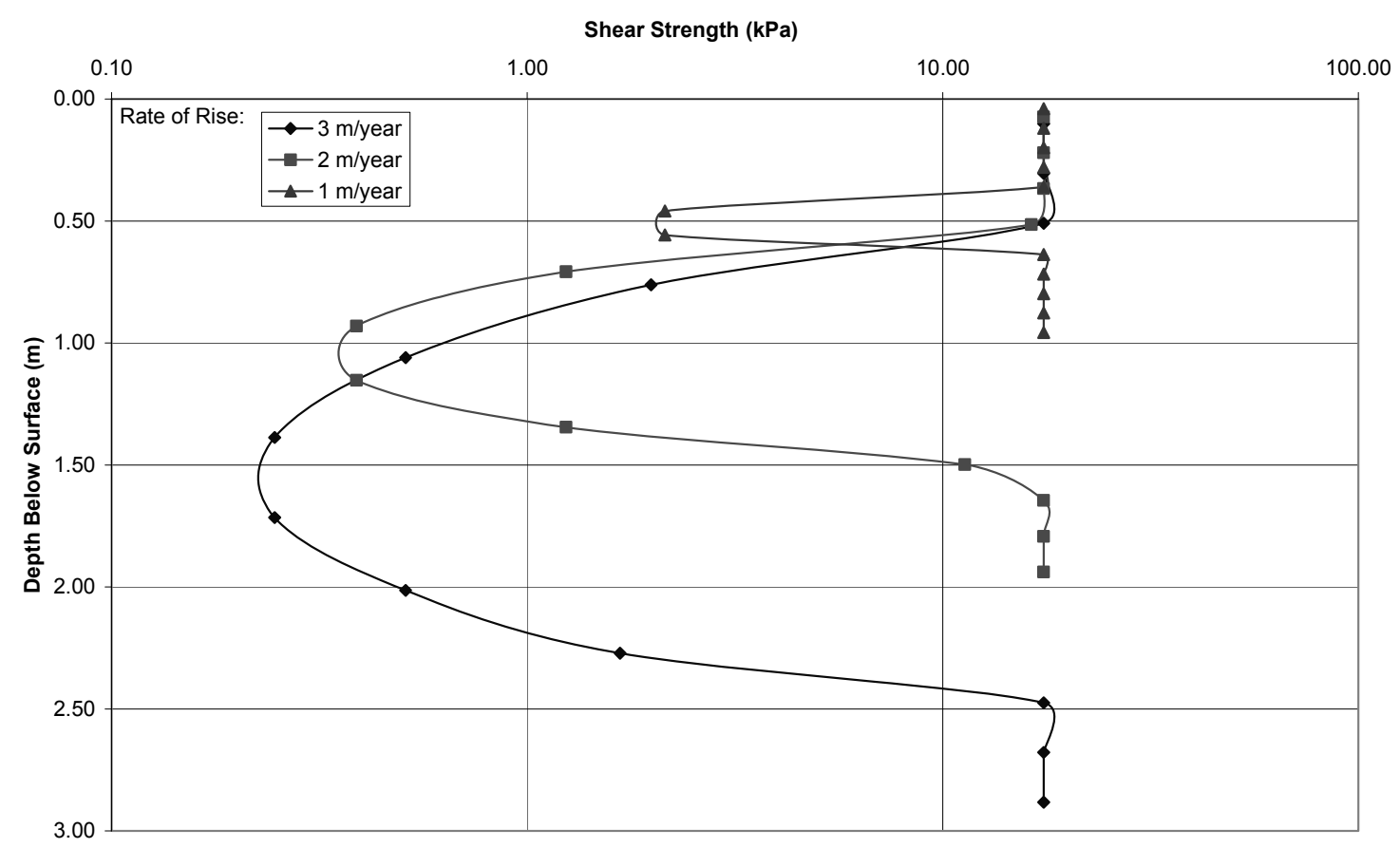

Figure 6 Monthly shear strength variation with changes in placement rate

For the purpose of this calculation, the peak values have been limited to the shear stress at the shrinkage limit density, but they would in fact be higher. However, it is the minimum values resulting from the winter months that are more important.

At a rate of rise of one metre per year the minimum undrained shear strength $\mathrm{S}_{\mathrm{u}}$ is only around $2 \mathrm{kPa}$. At higher rates of rise, the layers deposited in the winter have a shear strength of less than $1 \mathrm{kPa}$.

The consequence of these shear strengths for the stability of the beach slope can be readily calculated using infinite slope theory. If we consider a potential failure surface at some depth below a sloping surface, the undrained shear strength required for stability can be calculated as follows:

$$
\mathrm{s}_{\mathrm{u}}=\gamma \mathrm{gH} \sin \beta
$$


where:

$$
\begin{array}{ll}
\gamma & \text { is bulk density }\left(\mathrm{t} / \mathrm{m}^{3}\right) . \\
\mathrm{g} & =9.8 \mathrm{~m} / \mathrm{s}^{2} . \\
\mathrm{H} & \text { is the depth to the sliding surface }(\mathrm{m}) . \\
\beta & \text { is the slope angle (degrees). }
\end{array}
$$

For a slope angle of (e.g. $2 \%\left(\beta=1.15^{\circ}\right)$, a density $\gamma=1.8 \mathrm{t} / \mathrm{m}^{3}$, and a trial depth $\mathrm{H}=2 \mathrm{~m}$, the required shear strength $\mathrm{S}_{\mathrm{u}}=0.7 \mathrm{kPa}$. This is greater than the predicted minimum shear strength in the slope for a rate of rise in excess of $2 \mathrm{~m} /$ year, and under these conditions, the slope will fail.

At a discussion session at the Australian Centre for Geomechanics' Tenth International Seminar on Paste and Thickened Tailings 2007 in Perth, Eimco presented an example of a deep flow slide at the Kimberley tailings facility, without proposing a mechanism. Whilst details of the evaporation, tailings properties and depositional rates at Kimberley are not available to the authors of this paper, it is suggested that low strength layers resulting from winter deposition are the likely cause.

\section{Conclusions and final comments}

Undrained shear strength is a function of moisture content. In the context of soils (tailings) subject to evaporative drying this applies up to the shrinkage limit density.

In many cases a simple evaporative model is sufficient to quantify the changes in moisture content (and therefore density and strength) in tailings beaches.

In the case of thickened tailings beaches, some combinations of evaporation conditions, tailings characteristics, and rate of filling, may result in a static undrained failure of the tailings beach. Tailings having high clay fractions, therefore poor drainage properties and a low undrained strength ratio appear to be particularly susceptible.

It is emphasised that the shear strength versus moisture relationship summarised by Equation (4) is strongly non-linear. In critical applications it is strongly recommended that a sensitivity/risk analysis should be carried out to investigate the effects of variations in the input parameters.

\section{References}

Lambe, T.W. and Whitman, R.W. (1979) Soil mechanics, Drained and undrained stress-strain behaviour, Ch. 28, John Wiley and Sons.

Newson, T.A. and Fahey, M. (1998) Saline tailings disposal and decommissioning, Volume I Main Report. MERIWA Project No. M241, Australian Centre for Geomechanics, Western Australia.

Seddon, K.D. (2007) Post-liquefaction stability of thickened tailings beaches, Proceedings of the Tenth International Seminar on Paste and Thickened Tailings, A.B. Fourie and R.J. Jewell (eds), Australian Centre for Geomechanics, Peth, Australia, pp. 395-406.

Terzaghi, K. and Peck, R.B. (1967) Soil mechanics in engineering practice, 2nd edition, John Wiley and Sons.

Verburg, R., Ross, C., Dillon, M., Newman, P. and Fordham, M. (2006) Surface paste disposal of high-sulphide tailings - geochemical and geotechnical testing, Proceedings of the Ninth International Seminar on Paste and Thickened Tailings, R.J. Jewell, S. Lawson, P. Newman (eds), Australian Centre for Geomechanics, Perth, Australia, pp. 131-145. 


\section{Appendix: A note on units and terminology}

In the context of this paper, the term "moisture content" is used to denote water content using the soil mechanics convention of a dry weight basis. Moisture content $(\mathrm{m})$ is usually expressed as a percentage, but for convenience is used as a ratio in the equations presented in this paper, hence:

$$
\mathrm{m}=\text { Mass water/Mass soil. }
$$

The concept of void ratio (e) is also used, as this has the advantage of eliminating differences that are attributable to the soil particle density $(\mathrm{G})$.

Void ratio is defined as Volume water/Volume solids, and:

$$
\mathrm{m}=\mathrm{e} / \mathrm{G}
$$

The relationship between moisture content and the commonly used solids content $(\mathrm{S})$ is:

$$
\mathrm{m}=(100-\mathrm{S}) / \mathrm{S}
$$

where $\mathrm{S}$ is a percentage. 